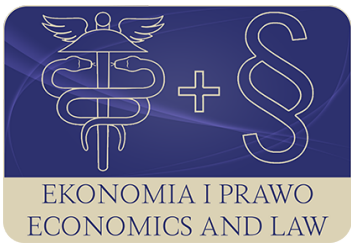

EKONOMIA I PRAWO. ECONOMICS AND LAW

Volume 15, Issue 3, September 2016

p-ISSN 1898-2255, e-ISSN 2392-1625

www.economicsandlaw.pl

EKONOMIA I PRAWO
ECONOMICS AND LAW

ORIGINAL ARTICLE

received 01.10.2015; revised 19.06.2016; accepted 30.09.2016

Citation: Podsiadło, P. (2016). State aid and the functioning of the Single European Market the crisis perspective. Ekonomia i Prawo. Ecomomics and Law, 15(3): 385-399. doi:10.12775/EiP.2016.026.

\title{
State aid and the functioning of the Single European Market - the crisis perspective
}

\author{
PIOTR PODSIADO \\ Cracow University of Economics, Faculty of Finance, Department of Local Government Finance, \\ ul. Rakowicka 27, 31-510 Cracow, Poland \\ $\square$ piotr.podsiadlo@uek.krakow.pl
}

\begin{abstract}
Motivation: The financial crisis and the collapsing of the financial market as a result of bankruptcy in 2008 of Lehman Brothers bank became the justification for the need for State intervention in order to prevent the bankruptcy of other financial institutions and related consequences for the real economy.
\end{abstract}

Results: Essential in this range was the position of the European Commission, whose task is to exercise control over compliance with European rules relating to the Member States intervention in the economy. A special role is played here by rules on granting State aid because their violation can lead to distortions of competition in the Single European Mar-

ket.

Aim: The aim of the article is to analyze the conditions of admissibility of State aid in the European Union, taking into account the rules applicable to the aid for undertak-

ings during the crisis.

Keywords: European Union; financial crisis; competition policy; state aid

JEL: E62; K20; K33

\section{Introduction}

Leading currently consideration within the structure and conditions of admissibility of State aid it should be noted that changes in EU policy of providing the aid have been introduced in response to the severe consequences of the financial crisis affecting the restriction of access to sources of finance and the cri- 
sis in the real economy shifting primarily into a decline in production, which together contributed to the crisis of public finances, namely crisis of excessive public debt and budget deficit resulting from the slowdown in different sectors of the economy. In particular Member States reported a decline in GDP, trade, significant limitations of production and expenditures on crucial investments, and also the rise in unemployment increasing social unrest. In such conditions, a significant decrease in demand, orders for raw materials and finished goods and the increasing problems of solvency of the buyers have become ordinary, which in turn contributed to the deterioration in the financial situation of enterprises, leading to inhibition of initiated or omission of new investments, changes in the structure of employment, and even the bankruptcy of certain business entities. At the same time tightening the policy of lending by banks significantly reduced the access of the enterprises to external sources of financing, thus impeding the ability to stay on the market, the implementation of new investment and further development. The actions of the State to support the economy have become in this situation one of the tools to oppose the increasing economic and social difficulties.

The aim of the article is to analyze the conditions of admissibility of State aid in the European Union, taking into account the rules applicable to the aid for undertakings during the crisis.

\section{The current state of knowledge}

The concept of state intervention carried out by fiscal policy has developed quite rapidly and gained new supporters till the seventies of the twentieth century, that is, until in many economies the phenomenon of stagflation was observed. The effectiveness of interventions recommended by the supporters of the Keynesian trend was significantly weakened when developing rapidly up till then the economies of Western countries fell into stagnation, reflected by the minimum rate of economic growth, increase in unemployment and high inflation (Owsiak, 2006, pp. 63-64). 'Just as the Great Depression caused doubting in the mechanisms of the free market and liberalism, so stagflation of the early seventies led to a retreat from Keynesian economics and the rebirth of classical ideas' (Godłów-Legiędź, 2005, p. 557). Existing then so-called oil crisis, which caused deep structural changes in the economies of individual countries, gave rise to criticism of State intervention carried out by fiscal policy, the effect of which was to be the violation of market mechanism, undermining the laws governing the market and the destruction of the economy resources. Monetarist revolution at the political level meant a return to the ideals of classical liberalism - to a free-market system with the limited role of the State in the economy. Raised objections to the idea of economic regulation, however, did not entirely negate the concept of state intervention, but has led to a shift of impact on the economy from fiscal instruments to monetary instruments. As the State was accused of increasing the budget deficit and public debt, which 
were the factors causing inflation, monetarists gathered around M. Friedman recognized as a fundamental issue the regulation of the money supply, mainly through indirect instruments, such as interest rates, exchange rates or required reserves rates. Monetarism as a determination of macroeconomic doctrine became a point of reference for most of the discussion on the role of the state in the economy and, consequently, in the eighties and nineties the twentieth century in the economic policy of highly developed countries the free market trends began to dominate.

At the beginning of the twenty-first century there was a return to the need for State intervention in economic processes. The financial crisis and the collapsing of the financial market as a result of bankruptcy in 2008 of Lehmann Brothers bank became the justification for the need for State intervention in order to prevent the bankruptcy of other financial institutions and related consequences for the real economy (Koenig, 2008, p. 3; D’Sa, 2009, p. 6). Financial institutions faced then three problems. These involved: the need of banks for additional capital because of reports by banks of large losses and declines in value of assets due to associated with their possession and difficult to assess exposure to risk, difficulties in raising funds by banks to refinance their activities as a result of perturbations in the market of long-term financial instruments, as well as the collapse of the interbank short-term loans market, which deprived the banks of their major source of liquidity. Essential in this range was the position of the European Commission, whose task is to exercise control over compliance with European rules relating to the Member States intervention in the economy. A special role is played here by rules on granting State aid because their violation can lead to distortions of competition in the internal market (Luja, 2009, p. 15; Lienemeyer \& Mouel, 2011, pp. 41-48; de Kok, 2015, pp. 224-240).

\section{The methodology of research}

The foundation of European Union policy in the area of State aid is the notation in Article 107 par.1 of the Treaty on the Functioning of the European Union (TFEU, OJ C326), according to which the State aid is inconsistent with the Internal market. Article 107 par. 1 TFEU states that: 'Subject to other provisions foreseen in the Treaties, any aid provided by a Member State or by means of State resources in any form, which disturbs or threatens to disturb the competition by favouring of certain enterprises or the production of certain goods shall be inconsistent with the Internal market within the scope as it affects the trade between Member States'. Therefore this is not the definition of inconsistent aid or consistent with the Internal market, but the definition of State aid as prohibited aid, provided it is not excluded from this prohibition under Article 107 par. 2 and 3 or Article 106 par. 2 TFEU, in other words based on the Treaty provisions, which mention directly the aid consistent with the Internal market.

Such a Treaty provision enables the adoption of a broad and flexible interpretation of the concept of 'State aid' (Schina, 1987, p. 13; D'Sa, 1998, p. 54). 
Furthermore, in the case of the concept of 'State aid' within the meaning of Article 107 par. 1 TFEU, which is broad and general, so-called the open texture of law is seen noticeably (Hart, 1997, pp. 124-135). The result is that there is no way to determine the meaning extent of that concept and the legal principle defining the prohibition of State aid entirely by reference to the semantic, dictionary meaning and formal inference rules.

Determining the extent of the semantic concept of State aid and the meaning of legal principle defining the prohibition of the State aid is established during legal discourse, which in this case is the proceeding in front of the Court of Justice of the European Union. The Court of Justice of the EU may be defined as 'court of precedent' because the formulated general rules within its jurisdiction point the guidelines for the interpretation and application of both Treaties, and the entire EU secondary legislation (Scheuring, 2010, p. 264). Therefore, in this article the analysis of State aid is conducted basing on the concept of state aid with the meaning given and constantly being given by the case law of the EU Courts.

\section{The research process}

State aid may be granted for the various purposes, and the main reason for its use is the correction of market failure. In such cases, State aid seems to be a necessary mechanism instrument of state intervention in the economy, both from the perspective of a particular Member State and the objectives of the European Union. However, it is quite often when State aid is granted to financially support the enterprises to protect the domestic economy from foreign competition. State aid, its intensity and potential group of the beneficiaries may be defined with the aims of the current economic and social policy. In such cases, aid provision violates the rules of the internal market in terms of equality - in the context of nationality - of enterprises involved in the trade of goods and affects trade within the European Union. Consequently, State aid distorts competition, which is unacceptable from the perspective of the whole Union.

\subsection{Article 107 of the Treaty}

State aid within the meaning of Article 107 par. 1 TFEU is a legal concept which must be interpreted on the basis of objective factors (Judgment of the Court of 16 May 2000, ECLI:EU:C:2000:248, p. I-3271, para 25; Judgment of the Court of 12 December 2000, ECLI:EU:T:2000:289, p. II-3871, para 95), without any recognition of the European Commission, whether a particular measure is or is not State aid (Judgment of the Court of 27 January 1998, ECLI:EU:T:1998:7, p. II-1, para 53). The essential element is therefore the objective nature of the concept of State aid that is expressed by the fact whether the aid will ultimately be seen as permissible (consistent with the Internal market) or prohibited (inconsistent with the Internal market), is determined by the effect that the aid 
induces in the Internal market. Hence Article 107 par. 1 TFEU contains a normative definition of the aid inconsistent with the Internal market. The interventions of the State or by using the State resources involving obtaining a selective advantage to enterprises that may disturb the competition in the Internal market and affect the trade between Member States, are inconsistent with the Internal market and prohibited, but may be consistent with the Internal market and acceptable to the realization of objectives determined in Article 107 par. 2 and 3 TFEU (Oldale \& Piffaut, 2009, pp. 14-16). Such purposes include, among others supporting certain economic activities, supporting regional development and the protection of cultural and historical heritage. Then Article 108 TFEU constitutes that the task to control the State aid rests on the European Commission and also impose an obligation on Member States to inform beforehand the Commission of any plans to provide aid (Quigley \& Collins, 2003, p. 2). Therefore, the control over State aid is exercised by the Commission, which gives consent, prohibits or conditions the given plan of providing the aid, which is a result of the assessment of the aid measure declared by a Member State for compliance with certain conditions - contained in a number of specific guidelines and statements of the Commission (For example: Commission Regulation (OJ L187/1); Communication from the Commission (OJ C216/1 and OJ C19/4).

\subsection{Treaty premises}

With the above Treaty principles the jurisdiction of the Court of Justice of the European Union derives four constitutive qualities of State aid. In other words, the rules of State aid apply only to measures that satisfy all four criteria listed in Article 107 par. 1 TFEU, which include (Judgment of the Court of 24 July 2003, ECLI:EU:C:2003:415, p. I-7747, para 75):

- the criterion of transferring the State resources (State aid rules cover only the measures involving a transfer of State resources by national, regional or local authorities, public banks, or foundations);

- the criterion of economic benefit (State aid should constitute an economic advantage that the enterprise would not have received in the ordinary course of business);

- the selectivity criterion (State aid must be selective and therefore must affect the balance between certain enterprises and their competitors);

- the criterion of the impact on the competition and trade (State aid must have a potential impact on the competition and trade between Member States).

The criterion for determining the prohibited aid is a public quality of the funds provided. The Court of Justice in its judgment on Steinike \& Weinlig indicates that the concept of State resources contains the funds financed by the burdens imposed statutory, managed and distributed on the legally regulated basis, even if the administration of such funds is done by the private entities and separate from the structures of public administration (Judgment of the Court of 22 March 1977, ECLI:EU:C:1977:52, p. 595). Also, the forms which involve increasing 
the benefits can be optional, as they depend on the rules applicable in the Member States. Treaties and secondary legislation do not contain the catalogue or examples of forms of aid, limiting itself merely to stating that the form can be optional (Judgment of the Court of 10 July 1986, ECLI:EU:C:1986:302, p. 2263, para 13; Judgment of the Court of 21 January 1999, ECLI:EU:T:1999:7, p. II-17, para 131). It results from the broad definition of State organs that may provide State aid, as well as the overall concept of aid that has been defined by definitional conditions in Article 107 par. 1 of the Treaty. This implies that the provisions of Article 107 TFEU involve a variety of direct financial transfers from the public authorities. These include grants and increasing the company's capital (Judgment of the Court of 13 March 1985, ECLI:EU:C:1985:113, p. 809), interest-free loans (Judgment of the Court of 30 April 1998, ECLI:EU:T:1998:77, p. II-717), loans given on preferential interest terms (Judgment of the Court of 19 October 2000, ECLI:EU:C:2000:570, p. I-8855; Judgment of the Court of 30 April 1998, ECLI:EU:T:1998:78, p. II-757, para 53), or without adequate security (Judgment of the Court of 3 July 2003, ECLI:EU:C:2003:387, p. I-6931) and extra payments to the loans or credit interest (Judgment of the Court of 7 June 1988, ECLI:EU:C:1988:284, p. 2855; Judgment of the Court of 19 September 2002, ECLI:EU:C:2002:508, p. I-7657; Judgment of the Court of 29 September 2000, ECLI:EU:T:2000:223, p. II-3207). It's also a sale of goods for a given enterprise at a reduced price (Judgment of the Court of 21 January 1976, ECLI:EU:C:1976:4, p. 1, para. 2; Judgment of the Court of 2 February 1988, ECLI:EU:C:1988:38, p. 219, para 28), the return of the part cost of purchased goods or services (Judgment of the Court of 24 February 1994, ECLI:EU:C:1994:70, p. I-561, para 13) and extra payment to the premiums for social security plan created under the program of collective redundancies (Judgment of the Court of 26 September 1996, ECLI:EU:C:1996:353, p. I-4551) implemented by the enterprise. Interpretation of Article 107 TFEU also applies to aid measures taking the form of indirect financial transfers, among which one can indicate the resignation of public claims (Judgment of the Court of 23 November 2006, ECLI:EU:T:2006:361, p. II-4483, para 169) and exemption from the duty of paying the fines or other financial penalties (Judgment of the Court of 1 December 1998, ECLI:EU:C:1998:579, p. I-7907, para 43; Judgment of the Court of 17 June 1999, ECLI:EU:C:1999:313, p. I-3735, para 42), the postponement of the claims payment term (Judgment of the Court of 10 May 2000, ECLI:EU:T:2000:123, p. II-2125), as well as informal tolerance of persistent state of not paying the taxes, fees and other receivables (Judgment of the Court of 12 October 2000, ECLI:EU:C:2000:559, p. I-8717; Judgment of the Court of 12 May 2005, ECLI:EU:C:2005:287, p. I-3875; Judgment of the Court of 21 October 2004, ECLI:EU:T:2004:312, p. II-3597). State aid may also include the state guarantees and various other protections of credits or loans payment in the situation where they allow the enterprise to obtain favourable interest rates compared to the currently adopted (Judgment of the Court of 27 June 2000, ECLI:EU:C:2000:345, p. I-4897 and ECLI:EU:C:1999:530, 
paras 47-48), and in the situation when the loan would not at all have been provided without presenting the appropriate guarantees from the public authorities (Judgment of the Court of 5 October 2000, ECLI:EU:C:2000:537, p. I-8237). Considered as State aid are often tax exemption or reduced tax rate (Judgment of the Court of 15 March 1994, ECLI:EU:C:1994:100, p. I-877; Judgment of the Court of 1 December 1998, ECLI:EU:C:1998:579, p. I-7907; Judgment of the Court of 3 March 2005, ECLI:EU:C:2005:130, p. I-1627), as well as tax deductions (Judgment of the Court of 19 May 1999, ECLI:EU:C:1999:251, p. I-2981; Judgment of the Court of 23 October 2002, ECLI:EU:T:2002:258, p. II-4217), reduction of the tax base (Judgment of the Court of 23 October 2002, ECLI:EU:T:2002:259, p. II-4259), reduction in employers' contributions to social security (Judgment of the Court of 2 July 1974, ECLI:EU:C:1974:71, p. 709; Judgment of the Court of 5 October 1999, ECLI:EU:C:1999:480, p. I-6639), as well as the postponement of tax payment (Judgment of the Court of 29 June 1999, ECLI:EU:C:1999:332, p. I-3913; Judgment of the Court of 19 September 2000, ECLI:EU:C:2000:467, p. I-6857) and causing a similar effect the special depreciation allowances (Judgment of the Court of 22 April 2008, ECLI:EU:C:2008:236, p. I-2767; Judgment of the Court of 22 January 2013, ECLI:EU:T:2013:30, p. II-1933). Furthermore, the aid can be a system in which the taxable profit of the enterprise is flat-rate defined as a percentage of the entire amount of operating expenses and costs, excluding the personnel costs and financial costs (cost plus method) (Judgment of the Court of 22 June 2006, ECLI:EU:C:2006:416, p. I-5479, paras 90-102). The aid may also include the provision of goods or services below the market value or on preferential terms, including for example the sale of land (Judgment of the Court of 6 March 2002, ECLI:EU:T:2002:59, p. II-1275, para 72; Judgment of the Court of 16 September 2004, ECLI:EU:T:2004:266, p. II3145 ), the supply of electricity at a preferential tariff for selected enterprises (Judgment of the Court of 29 February 1996, ECLI:EU:C:1996:64, p. I-723, para 10) providing logistical and commercial support (Judgment of the Court of 1 July 2008, ECLI:EU:C:2008:375, p. I-4777), provision of intangible assets of economic value without mutual consideration (e.g. providing a list of clients) (Judgment of the Court of 7 June 2006, ECLI:EU:T:2006:150, p. II-1531, paras 164-171), or concluding agreements on mutual provisions between public and private enterprises under the terms of the economic benefit to a private enterprise (Judgment of the Court of 13 January 2004, ECLI:EU:T:2004:2, p. II-1, para 107). In certain circumstances the prohibition of providing State aid formed by the Treaty will apply to the payments for public services (Judgment of the Court of 22 November 2001, ECLI:EU:C:2001:627, p. I-9067, para 27; Judgment of the Court of 24 July 2003, ECLI:EU:C:2003:415, p. I-7747, paras 87-95; Judgment of the Court of 27 November 2003, ECLI:EU:C:2003:640, p. I-14243, paras 22-40). This will apply to the purchase of services, which are not in fact necessary and required (Judgment of the Court of 1 June 2006, 
ECLI:EU:C:2006:356, p. I-4845; Judgment of the Court of 28 January 1999, ECLI:EU:T:1999:12, p. II-139).

\section{5 . The results of research}

The economic and financial crisis has threatened the integrity of the single market and increased the potential for anticompetitive reactions. At the same time, the crisis has increased the demand for a greater role of the State to protect the most vulnerable members of society and promote economic recovery. But it has also put strains on Member States' budgets, requiring fiscal consolidation and better use of scarce resources. Last but not least, it has increased the disparity in Member States' leeway to finance their policies.

Unprecedented economic turmoil, which hit the European economy in 2008, was initially triggered in 2007 by problems with sub-prime mortgage lending in the United States that impacted heavily on other financial markets, leading to a loss of confidence between financial institutions and a systemic crisis for the entire banking sector (Quigley, 2009, pp. 336-338). When European financial markets were first affected, some European banks encountered severe difficulties due to their exposure to collateralised debt obligations (CDOs) and because of their inherently unsustainable business model. In 2008, the general situation deteriorated further with the fall of Bear Stearns. European central banks addressed the liquidity crisis by injecting high amounts of liquidity into the financial markets. As the crisis of confidence among banks dramatically worsened in September 2008 with the bankruptcy of Lehmann Brothers, the financial crisis entered in a phase marked by very serious problems of prominent American and European banks and the efforts of governments to rescue distressed financial institutions. Essentially, the insolvency of Lehmann Brothers had ended a phase of an implicit rescue guarantee to banks which are "too big to fail'. This meant that banks stopped lending to each other.

In order to prevent insolvency of several banks, and potential contamination or negative spillover effects, Member States intervened with rescue measures in favour or individual banks in accordance with the Community rules on rescue aid for firms in difficulty (Community guidelines, OJ C244/2)1. Subsequently, as the Commission developed a certain experience based on its discussions with the Member States and their various proposals for tackling the crisis, the Commission was able to come with a coherent framework of measures.

Adoption by the European Commission in November 2008 the Economic Recovery Plan (Communication from the Commission, COM(2008) 800) was the first try to inhibit the deepening recession of the European economy and its reconstruction, which simultaneously is accompanied by structural reforms for

${ }^{1}$ From 1 August 2014 the provisions entered into force of the new guidelines on State aid for rescuing and restructuring non-financial undertakings in a difficult situation (Communication from the Commission (OJ C249/1)), which introduces some changes, most favorable to the beneficiaries - e.g. temporary restructuring support. 
realizing the priority targets resulting from the Lisbon Strategy. The European Economic Recovery Plan, on the one hand, reminded about the existing opportunities and conditions concerning providing the State aid as a reference point for interventions undertaken by Member States, on the other hand it showed, however, that the existing rules and permitted instruments of State aid may not be sufficient to solve capital and financial problems occurred in enterprises, which were mainly related to difficulties in access to credit. It should be however noted, that the changed by increasing socioeconomic difficulties due to the global crisis the European Commission's approach to State action to support the economy was not the same as excluding the State intervention in the market mechanism from the control of the Commission. The repair program clearly indicated that any action taken by the State to combat the effects of the global crisis must be compatible with the Internal market and competition rules, especially rules of admissibility of State aid. Hence, developed under the European Economic Recovery Plan temporary and more flexible rules for providing State aid in times of crisis for the real economy sectors formed the connection of the need to complement the existing rules on providing State aid with keeping an adequate control of the European Commission over the aid schemes in the Member States.

Europe's growth potential can be increased by better focussing public expenditure and by creating appropriate conditions for recovery to take off and last. Some of that public spending will take the form of State aid, be it in the form of direct expenditure, tax incentives, State guarantees or other. Stronger and better targeted State aid control can encourage the design of more effective growth-enhancing policies and it can ensure that competition distortions remain limited so that the internal market remains open and contestable. It can also contribute to improving the quality of public finances. After the crisis modernisation of State aid control is needed to strengthen the quality of the Commission's scrutiny and to shape that instrument into a tool promoting a sound use of public resources for growth-oriented policies and limiting competition distortions that would undermine a level playing field in the internal market. The current complexity of the substantive rules as well as of the procedural framework, applying equally to smaller and bigger cases, are still challenges to State aid control.

\section{Conclusion}

The evaluation of State aid admissibility can not be univocal. On the one hand, providing the State aid to enterprises is necessary to achieve a number of economic and social objectives that are impossible to achieve only with the efforts of enterprises. On the other hand, the aid would not only financially charge the society, but it can also cause 'favouring' of certain entities in relation to their competitors. Providing State aid therefore affects the terms of competition, resulting in bestowing the benefits to the recipients of this aid, which they would 
not achieve as a result of market mechanisms activity. It is as important that the lack of internal barriers hindering the trade between particular Member States of the European Union is a necessary condition for the efficient functioning of the Internal market and achieving the basic objectives of its formation, i.e. the economic growth and consequent improvement of the quality of life in the European Union. The existence of these barriers would create unequal conditions of competition to the enterprises and would not allow for occurring the effects of free action of the market forces, in particular, stimulating the growth of the efficiency of the conducted business. State aid provided by Member States may not, therefore, violate the principles of free competition within the internal market. The State aid control as one of the instruments of EU competition policy plays an important part in protecting and strengthening the internal market.

Taking into account the potential distortion of competition within the internal market, which was caused by the additional possibilities of granting state aid, the question is whether removing the restrictions for financing the business on the basis of the temporary legal framework, was only precedent in the EU competition law? Or maybe it will constitute from now on the starting point for the provision of public aid in large sizes due to the disturbances in particular markets? These are significant questions, because since 2005 the Commission carried out a program of public aid reform in the European Union, which was based on four guiding principles. These included: less and better directed public aid, precise economic approach, effective procedures, better enforcement, higher predictability and enhanced transparency and also shared responsibility between the Commission and the Member States. The Economic Recovery Plan has clearly indicated that all actions taken to create the fastest and most efficient access to external financing and unblocking the credits allowing continuation of the business, must be compatible with the internal market and competition rules, in particular public aid. Despite this, in some cases, the priorities of the public aid reforms were subject to 'temporary suspension'.

The lesson that comes from the experience of financial and economic crisis should be recognition of aid measures introduced in the context of the crisis for the ad-hoc and one-off operation, which was justified only with the size of the crisis effects for companies in various sectors. This aid should be subject to the rules of sectoral aid, which in the Union undergoes strict supervision and regulation, in particular, the rule 'one time last time', or 'the first time, while the last time'. Currently, most of the crisis effects have been mitigated and therefore the Member States should return to the state aid reform program and while granting it they should follow primarily the Commission's conclusion contained in the program that says 'in some cases there is a small probability, that all categories of aid, contributing to achieve the objectives of common interest, had a negative impact on competition at Union level' (Report from the Commission, COM/2010/701). Therefore so-called 'block exemptions' were included in the wider use, thus the measures meeting the criteria specified in such 
special instruments could be granted without prior notification to the Commission. This is essential to facilitate the procedure for granting aid and considerably accelerates the process. Member State after notification and approval of the aid program can basically provide individual aid without further notification to the Commission. Individual notification is required only in the event of substantial individual applications within the aid programs exceeding certain thresholds, and in the case of aid granted outside the program (ad hoc aid). It should be also highlighted that block exemptions are also an essential instrument for achieving medium and long term objectives specified in the anti-crisis aid programs, among which it was pointed to encourage companies to continually invest in the future, especially in economy based on sustainable growth. Promoting the future objectives, such as, for example investment in innovative and ecological technologies, perfectly blends into the categories of aid granted under block exemption.

\section{References}

Commission Regulation (EU) No 651/2014 of 17 June 2014 declaring certain categories of aid compatible with the internal market in application of Articles 107 and 108 of the Treaty (OJ L187/1).

Communication from the Commission on the application, from 1 August 2013, of State aid rules to support measures in favour of banks in the context of the financial crisis (OJ C216/1).

Communication from the Commission to the European Council - A European Economic Recovery Plan (COM(2008) 800).

Communication from the Commission: Guidelines on State aid for rescuing and restructuring non-financial undertakings in a difficulty (OJ C249/1).

Communication from the Commission: Guidelines on State aid to promote risk finance investments (OJ Cl9/4).

Community guidelines on State aid for rescuing and restructuring firms in difficulty (OJ C244/2).

D'Sa, R.M. (1998). European Community Law on State Aid. London: Sweet\&Maxwell.

D’Sa, R.M. (2009). 'Instant' State Aid Law in a Financial Crisis - A U-Turn? European State Aid Quarterly, 8(2).

de Kok, J. de (2015). Competition Policy in the Framework and Application of State Aid in the Banking Sector. European State Aid Quarterly, 14(2).

Godłów-Legiędź, J. (2005). Główny nurt współczesnej ekonomii: od formalizmu do nowego instytucjonalizmu. In H. Landreth, \& D.C. Colander (Eds.), Historia myśli ekonomicznej. Warszawa: PWN.

Hart, H.L.A. (1997). The Concept of Law. Second Edition. Oxford: Oxford University Press.

Judgment of the Court of 1 December 1998. Ecotrade Srl v Altiforni e Ferriere di Servola SpA (AFS). Case C-200/97 (ECLI:EU:C:1998:579). 
Judgment of the Court of 1 July 2008. Chronopost SA and La Poste v Union française de l'express (UFEX) and Others. Joined cases C-341/06 P and C-342/06 P (ECLI:EU:C:2008:375).

Judgment of the Court of 1 June 2006. P \& O European Ferries (Vizcaya) SA (C-442/03 P) and Diputación Foral de Vizcaya (C-471/03 P) v Commission of the European Communities. Joined cases C-442/03 P and C-471/03 P (ECLI:EU:C:2006:356).

Judgment of the Court of 10 July 1986. Kingdom of Belgium v Commission of the European Communities. Case 234/84 (ECLI:EU:C:1986:302).

Judgment of the Court of 10 May 2000. SIC — Sociedade Independente de Comunicação SA v Commission of the European Communities. Case T-46/97 (ECLI:EU:T:2000:123).

Judgment of the Court of 12 December 2000. Alitalia - Linee aeree italiane SpA v Commission of the European Communities. Case T-296/97 (ECLI:EU:T:2000:289).

Judgment of the Court of 12 May 2005. Commission of the European Communities v Hellenic Republic. Case C-415/03 (ECLI:EU:C:2005:287).

Judgment of the Court of 12 October 2000. Kingdom of Spain v Commission of the European Communities. Case C-480/98 (ECLI:EU:C:2000:559).

Judgment of the Court of 13 January 2004. Thermenhotel Stoiser Franz Gesellschaft mbH \& Co. KG and Others v Commission of the European Communities. Case T-158/99 (ECLI:EU:T:2004:2).

Judgment of the Court of 13 March 1985. Kingdom of the Netherlands and Leeuwarder Papierwarenfabriek BV v Commission of the European Communities. Joined cases 296 and 318/82 (ECLI:EU:C:1985:113).

Judgment of the Court of 15 March 1994. Banco de Crédito Industrial SA v Ayuntamiento de Valencia. Case C-387/92 (ECLI:EU:C:1994:100).

Judgment of the Court of 16 May 2000. French Republic v Ladbroke Racing Ltd and Commission of the European Communities. Case C-83/98 P (ECLI:EU:C:2000:248).

Judgment of the Court of 16 September 2004. Valmont Nederland BV v Commission of the European Communities. Case T-274/01 (ECLI:EU:T:2004:266).

Judgment of the Court of 17 June 1999. Industrie Aeronautiche e Meccaniche Rinaldo Piaggio SpA v International Factors Italia SpA (Ifitalia), Dornier Luftfahrt GmbH and Ministero della Difesa. Case C-295/97 (ECLI:EU:C:1999:313).

Judgment of the Court of 19 May 1999. Italian Republic v Commission of the European Communities. Case C-6/97 (ECLI:EU:C:1999:251).

Judgment of the Court of 19 October 2000. Italian Republic (C-15/98) and Sardegna Lines - Servizi Marittimi della Sardegna SpA (C-105/99) v Commission of the European Communities. Joined cases C-15/98 and C-105/99 (ECLI:EU:C:2000:570). 
Judgment of the Court of 19 September 2000. Federal Republic of Germany v Commission of the European Communities. Case C-156/98 (ECLI:EU:C:2000:467).

Judgment of the Court of 19 September 2002. Kingdom of Spain v Commission of the European Communities. Case C-114/00 (ECLI:EU:C:2002:508).

Judgment of the Court of 2 February 1988. Kwekerij Gebroeders van der Kooy BV and others v Commission of the European Communities. Joined cases 67, 68 and 70/85 (ECLI:EU:C:1988:38).

Judgment of the Court of 2 July 1974. Italian Republic v Commission of the European Communities. Case 173-73 (ECLI:EU:C:1974:71).

Judgment of the Court of 21 January 1976. Société des produits Bertrand SA v Commission of the European Communities. Case 40-75 (ECLI:EU:C:1976:4).

Judgment of the Court of 21 January 1999. Neue Maxhütte Stahlwerke GmbH and Lech-Stahlwerke GmbH v Commission of the European Communities. Joined cases T-129/95, T-2/96 and T-97/96 (ECLI:EU:T:1999:7).

Judgment of the Court of 21 October 2004. Lenzing AG v Commission of the European Communities. Case T-36/99 (ECLI:EU:T:2004:312).

Judgment of the Court of 22 April 2008. Commission of the European Communities v Salzgitter AG. Case C-408/04 P (ECLI:EU:C:2008:236).

Judgment of the Court of 22 January 2013. Salzgitter AG v European Commission. Case T-308/00 RENV (ECLI:EU:T:2013:30).

Judgment of the Court of 22 June 2006. Kingdom of Belgium (C-182/03) and Forum 187 ASBL (C-217/03) v Commission of the European Communities. Joined cases C-182/03 and C-217/03 (ECLI:EU:C:2006:416).

Judgment of the Court of 22 March 1977. Steinike \& Weinlig v Federal Republic of Germany. Case 78-76 (ECLI:EU:C:1977:52).

Judgment of the Court of 22 November 2001. Ferring SA v Agence centrale des organismes de sécurité sociale (ACOSS). Case C-53/00 (ECLI:EU:C:2001:627).

Judgment of the Court of 23 November 2006. Ter Lembeek International NV v Commission of the European Communities. Case T-217/02 (ECLI:EU:T:2006:361).

Judgment of the Court of 23 October 2002. Territorio Histórico de Álava Diputación Foral de Álava, Territorio Histórico de Guipúzcoa - Diputación Foral de Guipúzcoa and Territorio Histórico de Vizcaya - Diputación Foral de Vizcaya v Commission of the European Communities. Joined cases T-346/99, T-347/99 and T-348/99 (ECLI:EU:T:2002:259).

Judgment of the Court of 23 October 2002. Territorio Histórico de Guipúzcoa - Diputación Foral de Guipúzcoa, Territorio Histórico de Álava — Diputación Foral de Álava and Territorio Histórico de Vizcaya - Diputación Foral de Vizcaya v Commission of the European Communities. Joined cases T-269/99, T-271/99 and T-272/99 (ECLI:EU:T:2002:258).

Judgment of the Court of 24 February 1994. Fonderia A. SpA v Cassa Conguaglio per il Settore Elettrico. Case C-100/92 (ECLI:EU:C:1994:70). 
Judgment of the Court of 24 July 2003. Altmark Trans GmbH and Regierungspräsidium Magdeburg v Nahverkehrsgesellschaft Altmark GmbH, and Oberbundesanwalt beim Bundesverwaltungsgericht. Case C-280/00 (ECLI:EU:C:2003:415).

Judgment of the Court of 26 September 1996. French Republic v Commission of the European Communities. Case C-241/94 (ECLI:EU:C:1996:353).

Judgment of the Court of 27 January 1998. Ladbroke Racing Ltd v Commission of the European Communities. Case T-67/94 (ECLI:EU:T:1998:7).

Judgment of the Court of 27 June 2000. Commission of the European Communities v Portuguese Republic. Case C-404/97 (ECLI:EU:C:2000:345 and ECLI:EU:C:1999:530).

Judgment of the Court of 27 November 2003. Enirisorse SpA v Ministero delle Finanze. Joined cases C-34/01 to C-38/01 (ECLI:EU:C:2003:640).

Judgment of the Court of 28 January 1999. Bretagne Angleterre Irlande (BAI) v Commission of the European Communities. Case T-14/96 (ECLI:EU:T:1999:12).

Judgment of the Court of 29 February 1996. Kingdom of Belgium v Commission of the European Communities. Case C-56/93 (ECLI:EU:C:1996:64).

Judgment of the Court of 29 June 1999. Déménagements-Manutention Transport SA (DMT). Case C-256/97 (ECLI:EU:C:1999:332).

Judgment of the Court of 29 September 2000. Confederación Española de Transporte de Mercancías (CETM) v Commission of the European Communities. Case T-55/99 (ECLI:EU:T:2000:223).

Judgment of the Court of 3 July 2003. Kingdom of Belgium v Commission of the European Communities. Case C-457/00 (ECLI:EU:C:2003:387).

Judgment of the Court of 3 March 2005. Wolfgang Heiser v Finanzamt Innsbruck. Case C-172/03 (ECLI:EU:C:2005:130).

Judgment of the Court of 30 April 1998. Cityflyer Express Ltd v Commission of the European Communities. Case T-16/96 (ECLI:EU:T:1998:78).

Judgment of the Court of 30 April 1998. Het Vlaamse Gewest (Flemish Region) $\mathrm{v}$ Commission of the European Communities. Case T-214/95 (ECLI:EU:T:1998:77).

Judgment of the Court of 5 October 1999. French Republic v Commission of the European Communities. Case C-251/97 (ECLI:EU:C:1999:480).

Judgment of the Court of 5 October 2000. Federal Republic of Germany v Commission of the European Communities. Case C-288/96 (ECLI:EU:C:2000:537). Judgment of the Court of 6 March 2002. Territorio Histórico de Álava - Diputación Foral de Álava (T-127/99), Comunidad Autónoma del País Vasco and Gasteizko Industria Lurra, SA (T-129/99) and Daewoo Electronics Manufacturing España, SA (T-148/99) v Commission of the European Communities. Joined cases T-127/99, T-129/99 and T-148/99 (ECLI:EU:T:2002:59). Judgment of the Court of 7 June 1988. Hellenic Republic v Commission of the European Communities. Case 57/86 (ECLI:EU:C:1988:284). 
Judgment of the Court of 7 June 2006. Union française de l'express (UFEX), DHL International SA, Federal express international (France) SNC and CRIE SA v Commission of the European Communities. Case T-613/97 (ECLI:EU:T:2006:150).

Koenig, C. (2008). 'Instant State Aid Law' in a Financial Crisis, State of Emergency or Turmoil. European State Aid Quarterly, 7(4).

Lienemeyer, M., \& Mouel, L. (2011). The European Commission's Phasing Out Process for Exceptional Crisis-related Measures. European State Aid Quarterly, 10(1).

Luja, R. (2009). State Aid and the Financial Crisis: Overview of the Crisis Framework. European State Aid Quarterly, 8(2).

Oldale, A., \& Piffaut, H. (2009). Introduction to State aid law and Policy. In K. Bacon (Ed.), European Community Law of State Aid. Oxford: Oxford University Press.

Owsiak, S. (2006). Finanse publiczne. Teoria i praktyka. Warszawa: PWN.

Quigley, C. (2009). European State aid law and policy. Oxford-Portland Oregon: Hart Publishing.

Quigley, C., \& Collins, A.M. (2003). EC State Aid Law and Policy. Oxford-Portland Oregon: Hart Publishing Ltd.

Report from the Commission: State Aid Scoreboard Report on State aid granted by the EU Member States - Autumn 2010 Update (COM/2010/701).

Scheuring, K. (2010). Precedens w orzecznictwie Trybunatu Sprawiedliwości Unii Europejskiej. Warszawa: Oficyna a Wolters Kluwer business.

Schina, D. (1987). State Aids under the EEC Treaty. Articles 92 to 94, Oxford: ESC Publishing Ltd.

Treaty on the Functioning of the European Union — Consolidated version 2012 (OJ C326).

\section{Acknowledgements}

Author contributions: author have given approval to the final version of the article.

Funding: this research was fully funded by the Faculty of Finance at Cracow University of Economics, within the framework of the subsidy for the maintenance of research potential. 
